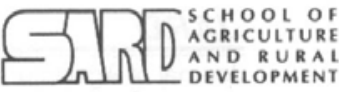

কৃষि ও পল्षী উन्नয়न অनूयদ
Available online at http:/ /www.banglajol.info/index.php/jard
J ARD

Journal of Agriculture

\& Rural Development

\title{
Assessment of Technical Efficiency of Potato Producers in Some Selected Areas of Bangladesh
}

\author{
M. A. HosSAIN, M. K. HASAN ${ }^{*} \&$ Q. NAHER \\ On Farm Research Division, Bangladesh Agricultural Research Institute, Gazipur-1701, Bangladesh
}

\begin{abstract}
A study was carried out in three potato growing areas viz. Munshiganj, Bogra and Jessore covering 75 potato growers to measure technical efficiency and economic performance of potato production. Farmers obtained average tuber yield of 24.90 t/ha which was higher than the average yield of Bangladesh (14.90 t/ha) but close to potential yield (25-30 t/ha) of diamant and cardinal varieties. The estimated results showed that gross margin and BCR for potato cultivation were Tk. 174319/ha and 2.40, respectively. The average level of technical efficiency among the sample farmers was $75 \%$. This implies that given the existing technology and level of inputs the output could be increased by $25 \%$. Training on the potato production, extension linkage and quality seed played a significant role in the technical efficiency of the potato production.
\end{abstract}

Key words: Profitability, technical efficiency, potato producers.

\section{INTRODUCTION}

Potato (Solanum tuberosum) is the third largest food crop in Bangladesh. Its area and production are increasing day by day (BBS, 2005). In declaring 2008, the international year of the potato, the UN General Assembly seeks to focus world attention on the role of potato in defeating hunger and poverty. Usually farmers follow a different level of production inputs and management depending upon their infrastructural facility and socio-economic condition which ultimately result variability in yields. Potato, a high biomass yielder, utilizes huge quantities of nutrient particularly nitrogen, phosphorus and potassium (Elias et al., 1992). The proper management of fertilizer is fully dependent upon the ability of the manager, his attitude, knowledge, skill and resource condition (Hossain and Islam, 1986). The relative efficiency in agricultural production is an important aspect in developing countries' agriculture (Radam and Latif, 1995). Farm efficiency has long been an area of interest in the investigation of farm operation. Farmers' production performance does not only depend on physical resources and technology available to them, but also on existing farm management conditions. Studies examining farming efficiency in developing countries, the production efficiency levels range $60-82 \%$ irrespective of crop types and regions (Rahman, 2003; Coelli et al., 2002; Wang et al., 1996). The efficient use of resources is an important indicator of increased production in agriculture. Efficient use of inputs can help farmers to get higher production from a given amount of resources. Several studies in other countries have shown that there is significant potential for raising agricultural output or profitability by improving productive (technical

* Corresponding author: Scientific Officer, OFRD, BARI, Gazipur-1701, E-mail: kamrulnk@yahoo.com

(C) 2008 School of Agriculture and Rural Development, Bangladesh Open University, All rights reserved. 


\section{K. Hasan et al.}

and allocative) efficiency using existing resources (Rahman, 2002). The present study was, therefore, designed to measure technical efficiency of potato producers.

\section{MATERIALS AND METHODS}

\section{Data collection}

Based on area and production, the present study was conducted in the potato growing districts of Bangladesh to collect primary data. Among the three districts, high, moderate and low concentrated area was selected for each potato growing areas. Munshiganj was chosen as high concentrated area, Bogra as moderate concentrated area and Jessore as low concentrated area for potato production. Two villages were selected purposively for collecting farm level data from each district. A total of 75 farmers (25 farmers from each district) were selected purposively. Data were collected during April-May 2007. Pre-testing was done before finalizing the interview schedule. Secondary data on area and production related to potato were also used to supplement the information that was collected through field survey.

\section{Empirical model}

The Cobb-Douglas production function is used for functional analysis of the data. It is the most widely used model for fitting agricultural production data, because of its mathematical properties, ease of interpretation and computational simplicity (Heady and Dillon, 1969). It is a homogeneous function that provides a scale factor enabling one to measure the return to scale and to interpret the elasticity coefficients with relative ease. It is also relatively easy to estimate because in logarithmic form it is linear and parsimonious (Beattie and Taylor, 1985). Thus, Cobb-Douglas specification provides an adequate representation of the agricultural production technology.

The empirical Cobb-Douglas frontier production function model with double log form can be expressed as:

$$
\begin{aligned}
\operatorname{Ln} Y_{i}= & \beta_{0}+\beta_{1} \operatorname{Ln} X_{1 i}+\beta_{2} \operatorname{Ln} X_{2 i}+\beta_{3} \operatorname{Ln} X_{3 i}+\beta_{4} \operatorname{Ln} X_{4 i}+\beta_{5} \operatorname{Ln} X_{5 i}+\beta_{6} \operatorname{Ln} X_{6 i} \\
& +\beta_{7} \operatorname{Ln} X_{7 i}+\beta_{8} \operatorname{Ln} X_{8 i}+\beta_{9} \operatorname{Ln} X_{9 i}+\beta_{10} \operatorname{Ln} X_{10 i}+v_{i}-u_{i}
\end{aligned}
$$

Where,

$\mathrm{Ln}=$ Natural logarithm,

$Y_{i}=$ Yield of potato of the $\mathrm{i}$-th farm $(\mathrm{kg} / \mathrm{ha})$

$X_{1 i}=$ Human labor used by the i-th farm (man-days/ha)

$X_{2 i}=$ Seed used by the $\mathrm{i}$-th farm $(\mathrm{kg} / \mathrm{ha})$

$X_{3 i}=$ Nitrogen used by the i-th farm (Tk/ha)

$X_{4 i}=$ Phosphorus used by the i-th farm ( $\left.\mathrm{kg} / \mathrm{ha}\right)$

$X_{5 i}=$ Potassium used by the i-th farm (kg/ha)

$X_{6 i}=$ Sulfur used by the i-th farm $(\mathrm{kg} / \mathrm{ha})$

$X_{7 i}=$ Cowdung used by the i-th farm ( $\left.\mathrm{kg} / \mathrm{ha}\right)$

$X_{8 i}=$ Ploughing cost of the i-th farm (Tk/ha)

$X_{9 i}=$ Pesticide cost of the i-th farm (Tk/ha)

$X_{10}=$ Irrigation cost of the i-th farm (Tk/ha)

$v_{i}-u_{i}=$ error term

$\mathrm{V}_{\mathrm{i}}$ 's were assumed to be independently and identically distributed random errors, had $\mathrm{N}$ $\left(0, \sigma_{v}^{2}\right)$ distribution. 


\section{Technical inefficiency effect model}

The $u_{i}$ 's in equation were non-negative random variables, assumed to be independently distributed such that the technical inefficiency effect for the $i^{\text {th }}$ farmer, $u_{i}$, were obtained by truncation of normal distribution with mean zero and variance, $\sigma_{u}^{2}$, such that

$U_{i}=\delta_{0}+\delta_{1} Z_{1 i}+\delta_{2} Z_{2 i}+\delta_{3} Z_{3 i}+\delta_{4} Z_{4 i}+\delta_{5} Z_{5 i}+\delta_{6} Z_{6 i}+\delta_{7} Z_{7 i}+\delta_{8} Z_{8 i}+W_{i}$

Where,

$Z_{1 i}=$ Ln operated land of the i-th farm operator (ha)

$Z_{2 i}=$ Age of the $\mathrm{i}$-th farm operator (years)

$Z_{3 i}=$ Education level of the $\mathrm{i}$-th farm operator (year of schooling)

$Z_{4 i}=$ Family size of the $\mathrm{i}$-th farm operator (persons/household)

$Z_{5 i}=$ Experience in potato farming of the $\mathrm{i}$-th farm operator (years)

$Z_{6 i}=$ Dummy for potato training of the $\mathrm{i}$-th farm operator ( $1=$ yes, $0=$ No)

$Z_{7 i}=$ Dummy for extension linkage of the $\mathrm{i}$-th farm operator ( $1=$ yes, $0=\mathrm{No}$ )

$Z_{8 i}=$ Dummy for seed source $(1=$ Govt. organization, 0 = otherwise)

$W_{i}$ s were unobservable random variables or classical disturbance term, which are assumed to be independently distributed, obtained by truncation of the normal distribution with mean zero and unknown variance, $\sigma^{2}$, such that $u_{i}$ is non negative.

The $\beta, \eta$ and $\delta$ coefficients are unknown parameters to be estimated, together with the variance parameters which are expressed in terms of

$$
\begin{aligned}
& \sigma^{2}=\sigma_{u}^{2}+\sigma_{v}^{2} \text { and } \\
& \gamma=\sigma_{u}^{2} / \sigma^{2}
\end{aligned}
$$

$\gamma$ is the ratio of variance of farm specific technical efficiency to the total variance of output and has a value between zero and one.

The estimates for all parameters of the stochastic frontier and inefficiency effect model was estimated in a single stage by using the Maximum Likelihood (ML) method with the help of computer software package FRONTIER 4.1 (Coelli, 1996).

\section{RESULTS AND DISCUSSION}

\section{Agronomic profile}

The study revealed that all the farmers used potato variety of Diamant and Cardinal. The average seed rate used by the farmers was 1.98 t/ha while Choudhury et al. (2006) suggested $2.20 \mathrm{t} / \mathrm{ha}$ seed rate for Munshiganj area. All the farmers apply high dose of nitrogen, phosphorus and potassium than the recommended dose. The average rate used by the farmers was $174,93,216$ and $58 \mathrm{~kg} / \mathrm{ha}$ of $\mathrm{N}, \mathrm{P}, \mathrm{K}$ and $\mathrm{S}$, respectively (Table 1) against the recommendation by Hussain et al., (2006) for $\mathrm{N}$ $(100-115 \mathrm{~kg} / \mathrm{ha}), \mathrm{P}(24-30 \mathrm{~kg} / \mathrm{ha}), \mathrm{K}(110-125 \mathrm{~kg} / \mathrm{ha})$ and $\mathrm{S}(18-22 \mathrm{~kg} / \mathrm{ha})$, respectively. The farmers of Munshiganj applied 3-4 times of higher dose of N, P and $\mathrm{K}$ fertilizer than the recommended dose in the potato field (Choudhury et al., 2006). Farmers believed that higher dose of fertilizer would be increased higher yield. But the previous study proved that fertilizer that applied by the farmers also increased the yield but it was not significant nor economically viable (Choudhury et al., 2006). Only $56 \%$ of the farmers were found to apply cowdung in the field. Farmers received an average yield of $24.90 \mathrm{t} / \mathrm{ha}$ (Table 1) which was higher than the average yield of Bangladesh (14.90 t/ha) (DAE, 
2007) but close to the potential yield of potato (Hussain et al., 2006). It was observed from the previous study potato yield varied from 30 to $38 \mathrm{t} /$ ha in different potato growing areas due to different fertilizer management options (Choudhury et al., 2006).

Table 1. Agro-economic profile of potato production in the study areas during 2007

\begin{tabular}{lcc}
\hline \multicolumn{1}{c}{ Item } & Agronomic profile & Economic performance (Tk.) \\
\hline A. Variable cost & & - \\
Cultivated area of potato (ha) & 0.61 & - \\
Variety used & Diamant /Cardinal & - \\
Sowing period & Last week of November to & \\
& first week of December & $25900(20.81)$ \\
Human labor (Man-days/ha) & 259 & $49600(39.85)$ \\
Seed (kg/ha) & 1984 & $2464(1.98)$ \\
Nitrogen (kg/ha) & 174 & $7922(6.36)$ \\
Phosphorus (kg/ha) & 93 & $6480(5.21)$ \\
Potassium (kg/ha) & 216 & $1600(1.29)$ \\
Sulfur (kg/ha) & 58 & $13900(11.17)$ \\
Cowdung (t/ha) & 2.78 & $4617(3.71)$ \\
Ploughing (no.) & $2-3$ & $1873(1.50)$ \\
Pesticide (no.) & $2-3$ & $973(0.78)$ \\
Irrigation (no.) & 2 & $4152(3.34)$ \\
Interest on operating capital (Tk.) & - & - \\
Harvesting period & Last week of February to 1st & - \\
Tuber yield(t/ha) & week of March & 119481 \\
$\quad$ Total variable cost & 24.90 & $5000(4.00)$ \\
B. Fixed cost (Rental value of land) & - & $124481(100)$ \\
C. Total cost (A + B) & - & 298800 \\
Gross return (Tk./ha) & - & 174319 \\
Gross margin (Tk./ha) & - & 2.40 \\
Benefit Cost Ratio (BCR) & - &
\end{tabular}

Figure in the parenthesis indicate percent of total cost

Note: Interest on operating capital has been calculated @ 12\% for 4 month period.

Input price (Tk./kg): Potato seed (tuber) $=25, \mathrm{~N}=14, \mathrm{P}=85, \mathrm{~K}=30$ and $\mathrm{CD}=0.50$, Potato tuber $=12$

\section{Economic performance}

Among the variable cost, seed cost incurred the single highest cost followed by human labor cost for potato cultivation. Only seed tuber cost is about $40 \%$ of total cost of production in potato cultivation (Anon, 2002). Another study showed that the seed cost was $50-60 \%$ of the total variable cost of potato production (Hoque et al., 2006). As potato is labor intensive for seed cutting, planting, mulching, fertilizer application, crop management, harvesting etc. it shared about $21 \%$ of the total variable cost (Table 1). Among the different inorganic fertilizers, phosphorus showed higher cost followed by potassium. The gross return, gross margin and BCR were obtained Tk. 298800/ha, Tk. 174319/ha and 2.40, respectively (Table 1). The BCR was close to Hoque et al., (2006) who found BCR for potato cultivation was 2.41 to 2.92 in different treatment of cut size and spacing.

\section{Effect of productivity variables}

The empirical results indicated that the co-efficient of seed rate and potassium were positive and significant, while that of nitrogen, cowdung, ploughing cost and irrigation cost were positive but not significant (Table 2). It indicated that seed rate and potassium had significant and positive impacts on potato production. It might be due to lower seed rate and potash loving nature of potato. The coefficient of human labor and phosphorus were found negative and significant. Sulfur and pesticide cost were found also negative but insignificant. Holding other things remaining constant, the yield of potato would be increased by 0.223 and $0.216 \%$ as farmers spent $1 \%$ additional money for seed and applied 1\% additional potassium, respectively. On the other hand, there was negative co-efficient found in human labor, phosphorus, sulfur and pesticide cost. It indicated that there was no need to invest on those items for potato production and if the investment was done on those items, the production would be decreased. 


\section{Effect of inefficiency variables}

The estimated coefficients showed that training, extension linkage and dummy for seed sources were negative and significant in the inefficiency effect model (Table 2). It indicated that potato production would be increased with the increase of training, extension linkage and good quality seed. There was a positive effect of education, family size and potato farming experience on potato production but not significant. There was negative effect of cultivated potato land area and farmers' age but insignificant.

Table 2. Maximum likelihood estimates of the stochastic Cobb-Douglas frontier production function and technical inefficiency model for potato in the study areas (average)

\begin{tabular}{|c|c|c|c|}
\hline Independent variables & Para- meters & Co-efficient & Standard error \\
\hline Stochastic frontier model: & & & \\
\hline Constant & $\beta_{0}$ & 0.792 & 0.996 \\
\hline Ln Human labor & $\beta_{1}$ & $-0.031^{*}$ & 0.359 \\
\hline Ln Seed & $\beta_{2}$ & $0.223^{*}$ & 0.635 \\
\hline Ln Nitrogen & $\beta_{3}$ & 0.015 & 0.638 \\
\hline Ln Phosphorus & $\beta_{4}$ & $-0.084^{*}$ & 0.541 \\
\hline Ln Potassium & $\beta_{5}$ & $0.216^{*}$ & 0.424 \\
\hline Ln Sulfur & $\beta_{6}$ & -0.046 & 0.051 \\
\hline Ln Cowdung & $\beta_{7}$ & 0.031 & 0.194 \\
\hline Ln Ploughing cost & $\beta_{8}$ & 0.051 & 0.209 \\
\hline Ln Pesticides cost & $\beta_{9}$ & -0.005 & 0.131 \\
\hline Ln Irrigation cost & $\beta_{10}$ & 0.009 & 0.282 \\
\hline Technical inefficiency model: & & & \\
\hline Constant & $\delta_{0}$ & 0.121 & 1.001 \\
\hline Ln cultivated area of potato & $\delta_{1}$ & 0.083 & 0.834 \\
\hline Farmers age (years) & $\delta_{2}$ & 0.011 & 0.024 \\
\hline Farmers education level (year of schooling) & $\delta_{3}$ & -0.021 & 0.062 \\
\hline Family size (person/farm) & $\delta_{4}$ & -0.030 & 0.086 \\
\hline Potato farming experience (years) & $\delta_{5}$ & -0.022 & 0.028 \\
\hline Dummy for potato training $(1=$ Yes, $0=\mathrm{No})$ & $\delta_{6}$ & $-0.269^{*}$ & 0.746 \\
\hline Dummy for Extension linkage $(1=\mathrm{Yes}, 0=\mathrm{No})$ & $\delta_{7}$ & $-0.165^{*}$ & 0.922 \\
\hline Dummy for seed source ( $1=$ Govt. org., $0=$ others) & $\delta_{8}$ & $-0.115^{\star}$ & 0.981 \\
\hline Variance parameters: & & & \\
\hline Sigma-squared & $\sigma^{2}$ & 0.075 & 0.046 \\
\hline Gamma & $\mathrm{y}$ & 0.968 & 0.480 \\
\hline Log likelihood function & & 25.806 & \\
\hline
\end{tabular}

* indicate significant at $5 \%$ level of probability

\section{Farm specific technical efficiency}

It is revealed that farm-specific technical efficiencies varied from 46 to $97 \%$ with a mean of $75 \pm 14 \%$. Maximum farmers were in the group of 71 to 80 followed by $81-90 \%$ efficiency group. Lower efficiency was in few farmers (Fig. 1).

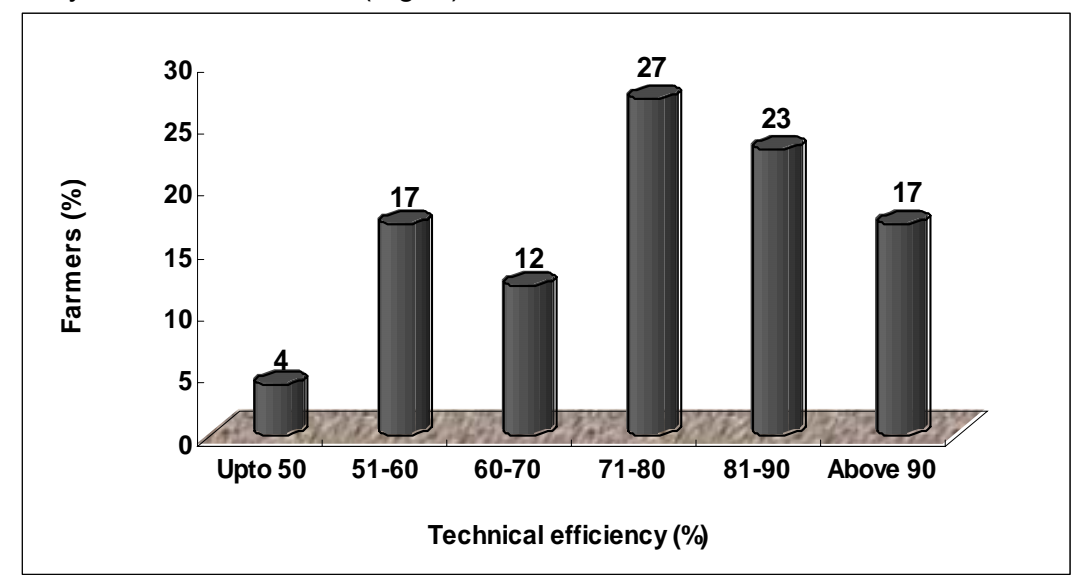

Fig. 1. Frequency distribution of technical efficiency of potato producers in the study areas 


\section{CONCLUSION}

The average technical efficiency is $75 \%$ which meant that the average inefficiency appeared to be $25 \%$. This implies that appropriate training to farmers on potato production and ensuring quality seed can play an important role in minimizing the technical inefficiency to a considerable extent.

\section{LITERATURE CITED}

BBS, 2005. "Yearbook of Agricultural Statistics in Bangladesh". Bangladesh Bureau of statistics, Ministry of Planning, Government of the People's Republic of Bangladesh, Dhaka, Bangladesh.

Beattie, B. R. and Taylor, C. R. 1985. "The Economics of Production". Montana State University, John Wiley \& Sons, New York, USA.

Choudhury, D. A., Quayyum, M. A., Hossain M. A. and Hasan. M. K. 2006 (Edited). Project completion report SFFP II (1999-2006). On Farm Research Division. Bangladesh Agricultural Research Institute, Joydebpur, Gazipur 1701. 383 pp.

Coelli, T., Rahman, S. and Thirtle, C. 2002. Technical, allocative, cost and scale efficiencies in Bangladesh rice cultivation: a non-parametric approach. J Agril Econ 53(3), 607-626.

DAE. 2007. "Krishi Dairy". Department of Agriculture Extension, Khamarbari, Farm gate, Dhaka.

Elias, S. M, Miah, M. R. U., Hossain, M. J., Torofder, G. S. and Islam, M. S. 1992. Effect of potassium on the growth and yield of potato. Bang J Agril Res 17(7), 91-93.

Heady, E. O. and Dillon, J. L. 1969. "Agricultural Production Functions". lowa State University Press, Ames.

Hoque, M. A., Hasan, M. K., Islam, M. R., Siddique, M. S. J. and Rahman, M. F. 2006. Effect of cut seed size and spacing on yield and profitability of potato. Bang J Agric Environ 2(1), 9-15.

Hossain, S. M. A. and Islam, M. S. 1986. Fertilizer management in Bangladesh. Advances in agronomic research in Bangladesh. In "Proceeding of a Symposium held in Bangladesh Agricultural Research Institute", Joydebpur, January 18-19, 1986. 48 pp.

Hussain, M. S., Rahman, M. M., Rashid, M. H., Farid, A. T. M., Quayyum, M. A., Ahamed, M., Alam, M. S. and Salehuddin, K. M. 2006 (Edited). "Krshi Projukti Hatboi" (Handbook on Agrotechnology, Fourth Edn.), Bangladesh Agricultural Research Institute, Joydebpur, Gazipur.

Radam, A. and Latiff, I. 1995. The technical efficiency of paddy farms in Malaysia: A Rayhomothetic production function study. Asian Econ Rev 37(3), 449-456.

Rahman, K. M. M. 2002. Measuring efficiency of producing rice in Bangladesh: A stochastic frontier analysis. Unpublished [PhD Thesis], Institute of Agricultural Policy and Marketing Research, Justus-Liebig University, Giessen, Germany.

Rahman, S. 2003. Profit efficiency among Bangladesh rice farmers. Food Policy 6, 28, 487-503.

Wang J., Cramer, G. L. and Wailes, E. J. 1996. Production efficiency of Chinese agriculture: evidence from rural household survey data. J Agril Econ 15(1), 17-28. 